\title{
The Yield and Composition of Milk in Sarda, Awassi, and Merino Sheep Milked Unilaterally at Different Frequencies
}

\author{
A. Nudda, ${ }^{*}$ R. Bencini, $†$ S. Mijatovic, $†$ and G. Pulina* \\ *Dipartimento di Scienze Zootecniche, \\ Universitá degli Studi di Sassari, Via E. De Nicola, 9, \\ 07100 Sassari, Italy \\ †School of Animal Biology, Faculty of Natural and Agricultural Sciences, \\ The University of Western Australia, 35 Stirling Highway, \\ Crawley, 6009
}

\section{ABSTRACT}

Sarda $(\mathrm{n}=8)$, Awassi $(\mathrm{n}=8)$, and Merino $(\mathrm{n}=8)$ ewes were subjected unilaterally to once-daily milking (ODM) or twice daily milking (TDM) to test the hypothesis that the two breeds highly selected for milk production (Sarda and Awassi) would not respond as much to a change in the frequency of milking as the Merino, a wool sheep that has not been selected for dairy production. Milk composition and somatic cell count (SCC) were also assessed to determine if the changes in milking frequency affected milk quality. Milk yield was $24 \%$ and $18 \%$ lower in ODM udder halves than TDM udder halves in Sarda and Awassi breeds, respectively. The yield loss due to ODM was similar to that observed in Merino ewes (23\%) and did not support our hypothesis. Fat content did not differ significantly in any breeds between ODM and TDM udder halves. Protein content was higher in the milk of ODM than TDM udder halves in Sarda and Merino ewes. The SCC was influenced by milking treatment only in the Sarda ewes, with high values observed in the milk of ODM udder halves. The same trend was observed in the Awassi and Merino breeds, but the differences were not significant. The effects on milk yield, composition, and SCC caused by ODM were completely reversed when TDM was resumed. This suggests that in sheep flocks the milk yield losses due to short-time suppression of one daily milking, for example, on festive days, are low and temporary. (Key words: sheep, milking frequency, milk yield, milk composition)

Abbreviation key: FIL = feedback inhibitor of lactation, $\mathbf{O D M}=$ once-daily milking, $\mathbf{T D M}=$ twice-daily milking.

Received February 16, 2002.

Accepted May 4, 2002.

Corresponding author: G. Pulina; e-mail: gpulina@uniss.it.

\section{INTRODUCTION}

In dairy sheep, once-daily milking (ODM) reduces milk yield (Morag, 1968; Labussière et al., 1974; Cannas et al., 1991) in comparison with twice-daily milking (TDM). However, ODM can be appealing in sheep flocks if milk yield losses due to the suppression of one daily milking, for example, on festive days are low and temporary.

It is known that unilateral alteration of the frequency of milking affects only the treated gland (Wilde and Knight, 1990; Auldist and Prosser, 1999), suggesting that milk secretion in the mammary gland is regulated locally by the Feedback Inhibitor of Lactation (FIL), a fraction of the whey proteins present in milk (Peaker and Wilde, 1987). Moreover, because the alveolar tissue is the site of action of the FIL (Henderson and Peaker, 1984), the effect of ODM on milk yield and composition would be expected to be smaller for animals with large mammary gland cisterns, due to the shorter contact time of milk with the alveoli. This hypothesis is supported by the finding that the milk production of cows with large cisterns was almost unaffected by changes in the frequency of milking (Knight and Dewhurst, 1994; Stelwagen and Knight, 1995; Stelwagen et al., 1996).

In sheep (Pulina, 1990; Bencini, 1993) and cattle (Stanton et al., 1992), the concentrations of fat and protein are lowest at the peak of lactation when the rate of synthesis of lactose is maximal, possibly because the rates of synthesis of protein and fat cannot keep up with that of lactose. However, Wilde et al. (1988, 1996) reported that, in dairy goats highly selected for milk production, the FIL acts equally on all milk components so that the composition of the milk does not vary when the frequency of milking is altered. In sheep, there have been few studies on the effects of milking frequencies on fat and protein production, and they reported contradictory results (Morag, 1968; Casu and Boyazoglu, 1974; Battaglini and De Maria, 1977). Such contrasting reports may be due to a difference between breeds of sheep based on their level of selection for milk production. 
Therefore, it is crucial to verify if effects of changes in milking frequency on milk yield and milk composition are different in breeds selected or not selected for milk production. To test this, we milked unilaterally Sarda, Awassi, and Australian Merino sheep once or twice daily. We compared milk yield and composition to test the hypothesis that the Sarda and Awassi breed, which are highly selected for milk production, would be less affected by changes in the frequency of milking than the Australian Merino, a wool sheep. We also measured SCC to verify if the variation in milking frequency resulted in stress to the mammary gland epithelium.

\section{MATERIALS AND METHODS}

\section{Animals and Management}

Eight Sarda primiparous ewes at the wk 15 of lactation were chosen from a flock in the north of Sardinia (Italy). Eight Merino and eight Awassi ewes, in their second to fourth lactation, also at the wk 15 of lactation, were chosen from a flock of sheep milked at The University of Western Australia, Perth, Western Australia.

Ewes were selected with the constraint that there be no sensible difference in milk yield between udder halves; average daily milk yields at the beginning of the experiment were $617 \pm 17.7 \mathrm{~g}, 460 \pm 32.2 \mathrm{~g}$, and $208 \pm 15.9 \mathrm{~g}$ for each udder half in Sarda, Awassi, and Merino, respectively. For the whole experimental period the animals were kept in paddocks and were hand-milked.

Sarda ewes were fed $1.5 \mathrm{~kg}$ of concentrate $(\mathrm{CP}=$ $15.20 \%$; $\mathrm{NDF}=43.81 \%$ ) distributed four times per day and meadow hay, available ad libitum. The Awassi and Merino ewes received $500 \mathrm{~g}$ each of lupins/d and $300 \mathrm{~g}$ of a feed mix (40\% oaten chaff, $30 \%$ lupin, $15 \%$ oats, and $15 \%$ barley) on the milking platform. They also grazed irrigated pasture composed predominantly of kikuyu, rye grass, and subterranean clover, along with meadow hay, available ad libitum. The above diet ensured energy requirements were satisfied to remove any interference of nutrition on our experiment.

\section{Experimental Design}

The experiment was conducted in early summer (May in Sardinia and November in Australia) so that both groups of animals were exposed to similar environmental conditions characterized by long day lengths and declining pasture nutritive value. Before the experiment, animals were milked twice daily with intervals between milkings of about $12 \mathrm{~h}$. In the last $2 \mathrm{~d}$ of the pre-experimental period, milk yields were recorded, and milk samples were collected separately for each udder half. In the first period of the experiment (4 d), the ewes were milked unilaterally at different frequencies: the right udder half was milked twice a day and the left once a day. In the second period ( $4 \mathrm{~d}$ ) the treatments were reversed. The two phases were separated by a 3d recovery period, during which TDM was resumed to remove carry-over effects. Milk yields were recorded and milk samples were collected for the last $3 \mathrm{~d}$ of each experimental period. Fat, protein $(\mathrm{TN} \times 6.38)$, and lactose content were determined, with a Milkoscan 605 and, for the Australian samples, with a MilkoScan 104 (Foss Electric, Hillerod, Denmark); both instruments were calibrated with the same procedure (AOAC, 1990; methods nos. 905.02, 920.105, and 984.15 for fat, protein, and lactose, respectively). SCC were determined with Fossomatic 360 cell counter (Foss Electric).

\section{Statistical Analysis}

Data for milk yield, fat, protein, and lactose content, and log-transformed SCC between milking treatments were analyzed using the following mixed linear model:

$$
\begin{aligned}
\mathrm{Y}_{\mathrm{ijkp}} & =\mu+\mathrm{B}_{\mathrm{i}}+\mathrm{M}_{\mathrm{j}}+\mathrm{P}_{\mathrm{k}}+\mathrm{E}_{\mathrm{p}}+(\mathrm{B} \times \mathrm{M})_{\mathrm{ij}} \\
& +(\mathrm{B} \times \mathrm{P})_{\mathrm{ik}}+(\mathrm{M} \times \mathrm{P})_{\mathrm{jk}}+\varepsilon_{\mathrm{ijkp}}
\end{aligned}
$$

where

$$
\begin{aligned}
\mathrm{Y}_{\mathrm{ijkp}}= & \text { observation of the dependent variable } \\
& \text { (milk, fat, protein, and lactose concentra- } \\
& \text { tions } \mathrm{SCC}) \\
\mu= & \text { overall mean } \\
\mathrm{B}_{\mathrm{i}}= & \text { fixed effect of breed } \mathrm{i}(\mathrm{i}=3) \\
\mathrm{M}_{\mathrm{j}}= & \text { fixed effect of milking treatment } \mathrm{j}(\mathrm{j}=2) \\
\mathrm{P}_{\mathrm{k}}= & \text { fixed effect of the experimental phase } \mathrm{k}(\mathrm{k} \\
& =1,2) \\
\mathrm{E}_{\mathrm{p}}= & \text { random effect of ewes } \\
\varepsilon_{\mathrm{ijkp}}= & \text { random residual }
\end{aligned}
$$

For the half udder milked twice-daily, the mean of two milkings was considered. Effects were considered to be significantly different at $P<0.05$, and tendencies were declared at $P<0.10$.

\section{RESULTS}

Milk yields, SCC, fat, protein, and lactose concentrations from the udder halves of Sarda, Merino, and Awassi sheep milked once or twice a day are reported in Table 1.

Milk yield was significantly higher in Sarda and lower in Merino ewes compared with Awassi ewes $(P<$ $0.01)$. Milk yield of ODM udder halves was lower than the yield from TDM udder halves in Sarda $(P<0.01)$ and Awassi $(P<0.05)$ ewes by $24 \%$ and $18 \%$, respec- 
Table 1. Least squares means of daily milk yields and composition of each udder halves in Sarda, Awassi, and Merino sheep milked once (ODM) or twice (TDM) a day.

\begin{tabular}{|c|c|c|c|c|c|c|c|c|}
\hline \multirow{2}{*}{ Variables } & & \multicolumn{3}{|c|}{ Breed $^{1}$} & \multirow[b]{2}{*}{$\mathrm{SEM}^{2}$} & \multicolumn{3}{|c|}{ Contrast, ${ }^{3} P$ value } \\
\hline & & Sarda & Awassi & Merino & & S vs. A & $\mathrm{S}$ vs. $\mathrm{M}$ & A vs. $M$ \\
\hline \multirow[t]{2}{*}{ Milk yield, g/d } & ODM & $472^{\mathrm{A}}$ & $325^{\mathrm{a}}$ & 139 & \multirow[t]{2}{*}{104.27} & $* *$ & $* *$ & $* *$ \\
\hline & TDM & $623^{\mathrm{B}}$ & $396^{\mathrm{b}}$ & 181 & & $* *$ & $* *$ & $* *$ \\
\hline \multirow[t]{2}{*}{ Fat, $\%$} & ODM & 6.69 & $7.48^{\mathrm{c}}$ & $8.31^{\mathrm{c}}$ & \multirow[t]{2}{*}{0.950} & $*$ & $* *$ & $* *$ \\
\hline & TDM & 6.44 & $6.86^{\mathrm{d}}$ & $7.67^{\mathrm{d}}$ & & NS & $* *$ & $* *$ \\
\hline \multirow{2}{*}{ Protein $(\mathrm{TN} \times 6.38), \%$} & ODM & $5.99^{\mathrm{A}}$ & $5.58^{\mathrm{c}}$ & $6.32^{\mathrm{A}}$ & \multirow{2}{*}{0.631} & $\dagger$ & NS & $* *$ \\
\hline & TDM & $5.41^{\mathrm{B}}$ & $5.15^{\mathrm{d}}$ & $5.66^{\mathrm{B}}$ & & NS & NS & $*$ \\
\hline \multirow[t]{2}{*}{ Lactose, $\%$} & ODM & 4.74 & $4.79^{c}$ & $4.61^{\mathrm{a}}$ & \multirow[t]{2}{*}{0.113} & NS & NS & NS \\
\hline & TDM & 4.88 & $5.02^{\mathrm{d}}$ & $4.86^{\mathrm{b}}$ & & NS & NS & NS \\
\hline \multirow[t]{2}{*}{$\mathrm{SCC} \times 1000, \log _{10}$} & ODM & $2.38^{\mathrm{a}}$ & 1.90 & 2.07 & \multirow[t]{2}{*}{0.220} & $* *$ & $\dagger$ & NS \\
\hline & TDM & $2.01^{\mathrm{b}}$ & 1.80 & 1.79 & & NS & NS & NS \\
\hline
\end{tabular}

${ }^{1}$ Subcolumn means between rows with different superscript $\operatorname{differ}\left({ }^{\mathrm{A}, \mathrm{B}} P<0.01\right.$; $\left.{ }^{\mathrm{a}, \mathrm{b}} P<0.05 ;{ }^{\mathrm{c}, \mathrm{d}} P<0.10\right)$.

${ }^{2}$ Pooled standard error of least squares means.

${ }^{3} \mathrm{~S}=$ Sarda; $\mathrm{A}=$ Awassi; $\mathrm{M}=$ Merino $(* * P \leq 0.01 ; * P \leq 0.05 ; \dagger P \leq 0.10$; NS not significant $P \geq 0.10)$.

tively. The extent to which milk secretion was reduced by ODM for the Merino breed (23\%) was similar to that observed in Sarda ewes, but the difference was not significant.

Daily milk yield did not differ between the two experimental periods in any breed (Figure 1) and, when the frequency of milking was returned to TDM, there was a full recovery in the rate of milk secretion. Fat content tended to be greater in ODM than TDM udder halves for the Awassi and Merino sheep $(P<0.1)$, whereas in the Sarda breed there was no difference in fat content. Contrast showed that fat content was significantly lower in Sarda ODM and higher in Merino ewes compared with Awassi ewes. Protein content was greater in the milk of ODM than TDM udder halves in Sarda and Merino ewes $(P<0.01)$. Contrast revealed a difference in milk protein content in Awassi versus Merino ewes for both frequencies of milking. Lactose content was lower in the milk of ODM than TDM udder halves for Merino $(P<0.05)$ and Awassi $(P<0.1)$ ewes, whereas in Sarda ewes it did not vary. No differences between breeds were detected for lactose content.

The effect of period was not significant for fat, protein, and lactose contents, and when TDM was resumed they returned to pretreatment values.

Milking treatment influenced SCC only in the Sarda ewes, where high values in the milk of ODM udder halves were observed $(P<0.05)$. The same trend was observed in Awassi and Merino breed, but the difference failed to reach significance. The increase in SCC due to the reduction of milking frequency was temporary, because when TDM was restored, SCC returned to pretreatment values.

Interactions were not significant $(P>0.1)$ except for that of breed $\times$ milking for milk yield $(P<0.01)$. Individual variability affected the response to the treatment for all the variables considered, as showed by the statistical significance $(P<0.01)$ of the random effect of animal.

\section{DISCUSSION}

Milk yield obtained from each udder half milked twice a day was within the range of estimates that have been recorded for the same breeds in the middle and the end of lactation (Bencini, 1993; Gursoy et al., 2001; Sanna et al., 2001).

The hypothesis that breeds highly selected for milk production, such as the Awassi and the Sarda, would respond less to a decrease in the milking frequency than Merinos was not supported by our results. All three breeds responded to ODM with production losses within a narrow range of 18 to $24 \%$, similar to previous findings in sheep (Labussière et al., 1974; Battaglini et al., 1979; Papachristoforou et al., 1982) where milking frequency was altered in all glands.

A reduction in milking frequency from TDM to ODM produced a significant decrease in milk yield only in Sarda and Awassi sheep, which are highly selected for milk production. Although in the Merino ewes milk yield was decreased by the reduction in milking frequency, the difference failed to reach significance. This could be due to the fact that our Merino ewes were not exposed to milking frequencies normally experienced when they nurse their lambs. If we had increased the frequency of milking to simulate the suckling of lambs, we may have obtained a different response (Bencini, 1993).

The significant reduction in milk yield observed in the Sarda and Awassi breeds does not support the hypothesis that these breeds would not respond to a reduced frequency of milking because they have been selected for high milk yield and so for large udder storage 
Sarda Breed

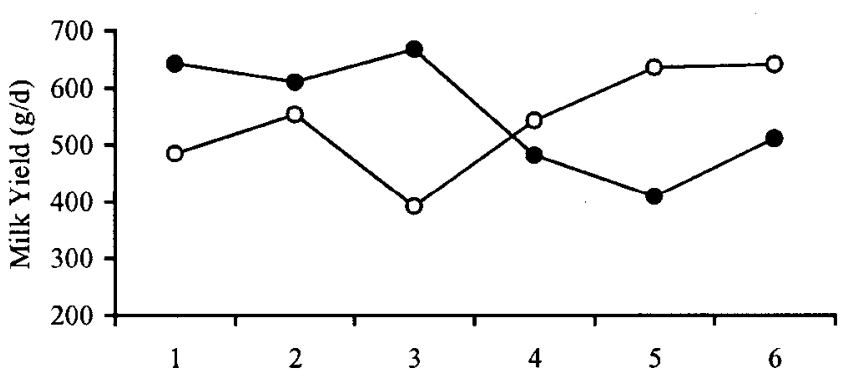

Awassi Breed

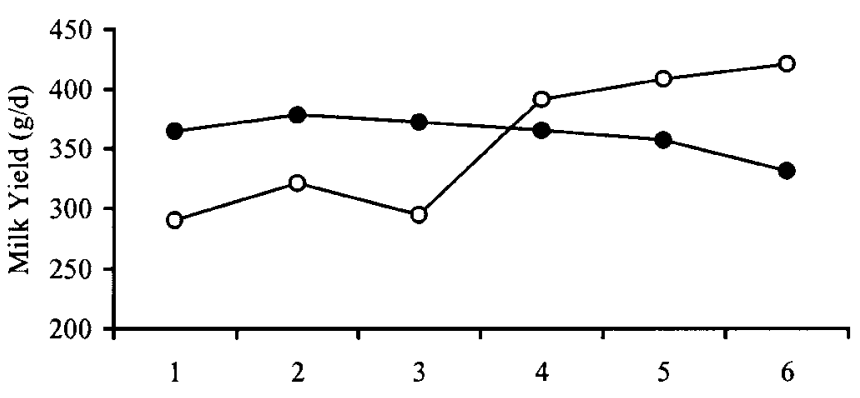

Merino Breed

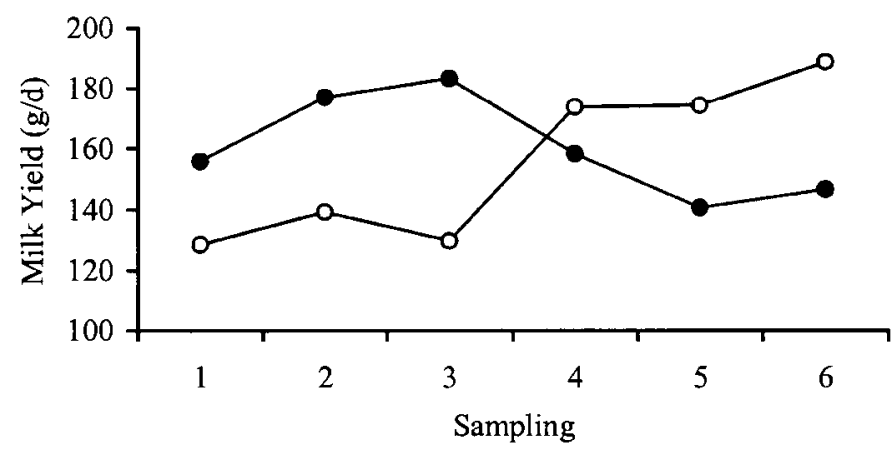

Figure 1. Milk production $(\mathrm{g} / \mathrm{d})$ of right $(\bullet)$ and left $(\bigcirc)$ udder halves milked once or twice a day. The right udder halves were subjected to TDM for the first period of the experiment and to ODM in the second period. The left udder halves received the reciprocal treatment and were subjected to ODM in the first period and to TDM in the second period.

capacities (Pulina and Nudda, 1996). Sarda sheep characterized by large cistern volume and a high cistern milk fraction (82\%, Nudda et al., 2000) showed the greater reduction in milk yield. It is possible that the volume of milk produced by the Sarda and Awassi sheep in this experiment was greater than that of their mammary gland cisterns, so local inhibition of milk secretion did occur in these specialized dairy sheep.
In Sarda ewes, production losses of 37\% due to ODM were previously reported by Cannas et al. (1991). Similar or greater production losses with ODM were observed in other high-producing breeds such as Prealpes du Sud (Labussière et al., 1974), Lacaune (Labussière et al., 1983), and Churra (Purroy Unanua and Martin Diaz, 1983). This association between the extent of the response to ODM and the level of production has been observed also in cows (Auldist and Prosser, 1999).

The TDM gland did not show an increase in milk production due to the greater availability of nutrient supply caused by the suppression of milking in the opposite gland (systemic factor). This is in contrast with the early report by Morag (1968) that when one udder half was milked less frequently the other responded by producing more (Wilde and Peaker, 1990).

The reduction in milk yield is due to localized factors, as unilateral ODM reduced milk secretion only in the ODM gland and not in the other TDM gland. The exact mechanisms by which milk secretion is reduced by the FIL are still not fully understood, but the fact that the effect was unilateral confirms that the secretion of milk is controlled also in dairy sheep by a local mechanism, as observed in goats (Wilde and Knight, 1990) and cows (Hillerton et al., 1990).

The effect of ODM on milk yield and composition is a "short-time effect" as milk secretion returns to pretreatment values as soon as milking frequency is restored. Such a complete reversibility of the response to milking frequency seems surprising because all ewes were in an advanced stage of lactation, when a reduction of milking frequency should result in a loss of mammary gland tissue and an irreversible loss of milk yield (Wilde and Peaker, 1990). As rate of milk production is a function of the number of secretory epithelial cells and their metabolic activity, we suppose that FIL acts on the latter and that no more milk has been produced by the TDM gland because their rate of synthesis was saturated by milk precursor supply.

The fact that fat concentration did not vary significantly seems in agreement with the reports of Wilde et al. $(1988,1996)$, who stated that the FIL is involved in the modulation of the synthesis of all the major components of milk, so that the composition of milk would not be affected by changes in milking frequency.

Instead, the concentration of protein was significantly higher in ODM than TDM udder halves in Sarda and Merino breeds. So it appears that the reports of Wilde et al. $(1988,1996)$ that milk composition would be unaffected by changes in the milking frequency cannot be applied in the same manner to fat and protein. Because the biochemical pathways for the synthesis of fat and protein are different, it would seem unlikely 
that the FIL may act on both pathways to the same extent.

The result for the SCC showed a significant increase only in ODM udder halves of Sarda ewes, and it exceeded the level usually considered as a threshold for subclinical mastitis (Ranucci and Morgante, 1994; González-Rodríguez et al., 1995). This could be explained by a concentration of SCC in the milk of ODM udder half due to high yield loss. This situation is clearly transient because when TDM was restored, the values for SCC returned to pretreatment values. Such result is in agreement with previous finding in cows (Stelwagen and Lacy-Hulbert, 1996), where an increase in SCC in animals exposed to ODM for the same short period has been observed. This study also demonstrates that high SCC counts induced by a change in milking frequency in sheep milk may be temporary and not necessarily due to mammary gland infections.

\section{CONCLUSIONS}

The unilateral decrease in milking frequency from TDM to ODM reduced milk yield only in the udder halves that had been milked once daily, indicating that local control of milk secretion is present also in sheep. The response in yield losses due to ODM was observed only in dairy breeds. The short-time effect of ODM indicates that the suppression of milk production due to one milking daily is feasible in the middle and advanced stage of lactation for a short-time period with yield losses of about $20 \%$ and without major alteration of milk composition.

A practical implication for the sheep dairy industry is that one daily milking can be temporarily omitted, for example, on festive days or in labor shortage circumstances, in the middle and final part of lactation without compromising the economic returns of the enterprise.

\section{ACKNOWLEDGMENTS}

We wish to thank Antonio Mazza, Antonio Fenu, and David McFerran for the technical assistance. This research was funded by the Ministero per le Politiche Agricole e Forestali (Mipaf, Italy) and by the Rural Industries Research and Development Corporation (RIRDC, Australia).

\section{REFERENCES}

Association of Official Analytical Chemists, International. 1990. Official Methods of Analysis. 15th ed. AOAC, Arlington, VA.

Auldist, M. J., and C. G. Prosser. 1999. Differential effects of short term once-daily milking on milk yield, milk composition and concentrations of selected blood metabolites in cows with low or high pasture intake. Proc. New Zealand Soc. Anim. Prod. 59:41-43.

Battaglini, A., and C. De Maria. 1977. Influenza della soppressione di una mungitura giornaliera sulla produzione e su talune carat- teristiche fisico chimiche del latte di pecore di razza Sopravissana. Ann. Ist. Sper. Zootec. 10:73-92.

Battaglini, A., C. De Maria, S. Dell'Aquila, and L. Taibi. 1979. Effetti della soppressione di una mungitura giornaliera sulla produzione e su talune caratteristiche qualitative del latte di pecore di razza Comisana. Ann. Ist. Sper. Zootec. 12:1-11.

Bencini, R. 1993. The sheep as a dairy animal: Lactation, production of milk and its suitability for cheese making. Ph.D. thesis, Univ. Western Australia, Perth.

Cannas, A., G. Pulina, S. P. G. Rassu, and N. P. P. Macciotta. 1991. Influenza della terza mungitura sulla produzione quanti-qualitativa in pecore di razza Sarda. Pages 1769-1772 in Proc. 45th Natl. Mtg. Soc. Ital. Sci. Vet., S. I. S.Vet., Altavilla Milicia, Italy.

Casu, S., and G. Boyazoglu. 1974. Effets de la suppression de la traite du soir chez la brebis Sarde. Ann. Zootech. ${ }^{\circ}$ hors-série 139-144.

González-Rodríguez, M. C., C. Gonzalo, F. San Primitivo, and P. Cármenes. 1995. Relationship between somatic cell count and intramammary infection of the half udder in dairy ewes. J. Dairy Sci. 78:2753-2759.

Gursoy, O., G. E. Pollott, and K. Kirk. 2001. Milk production and growth performance of a Turkish Awassi flock when outcrossed with Israeli Improved Awassi rams. Liv. Prod. Sci. 714:31-36.

Henderson, A. J., and M. Peaker. 1984. Feed-back control of milk secretion in the goat by a chemical in milk. J. Physiol. 351:39-45.

Hillerton, J. H., C. H. Knight, A. Turvey, S. D. Wheatley, and C. J. Wilde. 1990. Milk yield and mammary function in cows milked four times daily. J. Dairy Res. 57:285-294.

Knight, C. H., and R. J. Dewhurst. 1994. Once daily milking in dairy cows: Relationship between yield loss and cisternal milk storage. J. Dairy Res. 61:441-449.

Labussière, J., B. Bennemederbel, J. F. Combaud, and F. De La Chevalerie. 1983. Description des principaux parametres caracterizant la production laitiere, la morphologie mammarie et la cinetique d'emission du lait de la brebis Lacaune traite une ou deux fois par jour avec ou sans eguttages. Pages 625-652 in Proc. 3rd Int. Symp. Ordeno Mecanico Pequenos Ruminantes, Valladolid, Spain.

Labussière, J., J. F. Combaud, and P. Petrequin. 1974. Influence de la frequence des traites et des tetees sur la production latiere des brebis Prealpes du Sud. Ann. Zootech. 23:445-457.

Morag, M. 1968. The effect of varying the daily milking frequency on the milk yield of the ewe and evidence on the nature of the inhibition of milk ejection by half udder milking. Ann. Zootech. 17:351-369.

Nudda, A., G. Pulina, R. Vallebella, R. Bencini, and G. Enne. 2000. Ultrasound technique for measuring mammary cistern size of dairy ewes. J. Dairy Res. 67:101-106.

Papachristoforou, C., A. Roushias, and A. P. Mavrogenis. 1982. The effect of milking frequency on the milk production of Chios ewes and Damascus goats. Ann. Zootech. 31:37-46.

Peaker, M., and C. J. Wilde. 1987. Milk secretion: Autocrine control. News Physiol. Sci. 2:124-126.

Pulina, G. 1990. The effect of nutrition on the quality of sheep milk. L'Inf. Agr. 37:31-39.

Pulina, G., and A. Nudda. 1996. Fattori tecnici e fisiologici della mungitura meccanica degli ovini. L'Inf. Agr. 41:69-74.

Purroy Unanua, A., and J. L. Martin Diaz. 1983. Caracteristicas de ordeno de la oveja Churra: Produccion y composition de leche; morfologia de la ubre y cinetica de emission de leche. Pages 568583 in Proc. 3rd Int. Symp. Ordeno Mecanico Pequenos Ruminantes, Valladolid, Spain.

Ranucci, S., and M. Morgante. 1994. Sanitary control of the sheep udder: Total and differential cell counts in milk. Pages 5-16 in Proc. Int. Symp. Somatic Cell Counts and Milk of Small Ruminants, Bella, Italy.

Sanna, S. R., S. Casu, G. Ruda, A. Carta, S. Ligios, and G. Molle 2001. Comparison between native and synthetic sheep breeds for milk production in Sardinia. Liv. Prod. Sci. 71:11-16.

Stanton, T. L., L. R. Jones, R. W. Everett, and S. D. Kachman. 1992. Estimating milk, fat and protein lactation curves with a test day model. J. Dairy Sci. 75:1691-1700. 
Stelwagen, K., and C. H. Knight. 1995. Effect of simultaneous once (ODM) or twice (TDM) daily milking of cows during early and late lactation on milk yield and udder characteristics. J. Dairy Sci. 78:204. (Abstr.)

Stelwagen, K., C. H. Knight, C. F. Farr, S. R. Davis, C. G. Prosser, and T. B. McFadden. 1996. Continuous versus single drainage of milk from the bovine mammary gland during a 24 hour period. Exp. Physiol. 81:141-149.

Stelwagen, K., and S. J. Lacy-Hulbert. 1996. Effect of milking frequency on milk somatic cell count characteristics and mammary secretory cell damage in cows. Am. J. Vet. Res. 57:902-905.
Wilde, C. J., C. V. P. Addey, M. J. Casey, D. R. Blatchford, and M. Peaker. 1988. Feedback inhibition of milk secretion: The effect of a fraction of goat milk on milk yield and composition. Quart. J. Exp. Physiol. 73:391-397.

Wilde, C. J., C. V. P. Addey, and M. Peaker. 1996. Effects of immunization against an autocrine inhibitor of milk secretion in lactating goats. J. Physiol. 49:465-469.

Wilde, C. J., and C. H. Knight. 1990. Milk yield and mammary function in goats during and after once-daily milking. J. Dairy Res. 57:441-447.

Wilde, C. J., and M. Peaker. 1990. Autocrine control of milk secretion. J. Agric. Sci. (Camb.) 114:235-238. 